\title{
Is zero the safe real rate?
}

\author{
Andreas Mix \\ Institute for political science, \\ Justus-Liebig-University Gießen, \\ andreas.mix@sowi.uni-giessen.de
}

\begin{abstract}
:
The current economic debate with regards to the secular trend of ever lower, even negative, safe real interest rates is dominated by Keynesian, neoclassical and Austrian explanations. The former (two) argue that the interdependence phenomena of a global savings glut and a secular stagnation cause an oversupply of savings and thus drive down rates. From this position, central bank merely react to market forces. The latter dissent and argue that it was rather the other way around and an asymmetric central bank policy aimed at propping up equity prices led to the secular stagnation now quoted for its justification. In contrast, from the perspective of a critique of ideology, safe real rates where neither driven down by market forces nor central banks but by the weight of being not reasonably safe but riskless. Specifically, I argue that by equating the riskless return with the short-term interest rate, Black and Scholes (1973) state a tautology and imply that both rates shall be zero. In the subsequent inquiry, I show that this argument allows for a neat narration of the economic history of the neoliberal age. Furthermore, I explain why under current conditions ultralow interest rates fail to translate into inflation.
\end{abstract}

Keywords: Ideology critique, safe real rates, Keynesian economics, neoclassical economics, Austrian economics, secular stagnation, global savings glut, monetary policy, central banks, economic history, inflation. 


\section{Introduction}

With the latest pivot towards policy easing by the Federal Reserve in the summer of 2019, it was proven that some ten years after the Great Recession all of the world's major central banks are still struggling to 'normalize' monetary policy. Put simply, central banks face the conundrum that a decade of ultraloose monetary policy has helped to bring about a long stretch of economic expansion and record employment, albeit - significantly - until now it has failed to result in inflation. In other words, the economic data of recent years has never allowed central banks to engage in any serious campaign of monetary tightening. This situation is somewhat alarming as it looks as if the secular decline of the safe real rates of the developed world's economies since the early-1980s has found an uneasy equilibrium at the effective lower bound of zero for now, from which it seemingly can neither rise nor fall much (Yellen 2016).

Adding to the urgency of the search for a convincing explanation for the certainly unusual phenomenon of capitalism without interest is the profound disagreement about its origins in between economists. In a recent article summarizing the Keynesian and neoclassical, i.e. mainstream, thinking about the reasons for this occurrence, Lunsford and West find three perspectives on "drivers of US safe real rates" in the existing literature, namely "[1.] movements in growth (...) [2.] aggregate desired savings and investment (...) [as well as] [3.] some reduced-form work [that] has looked at some additional factors" (Lunsford and West 2019, p. 114). Despite their differences, all three perspectives hold in common that interest rates are driven by exogenous factors (Mayer and Schnabl 2019, p. 2). In other words, Keynesian and neoclassical economist share the believe, that interest rates are a reflection of economic activity and that central banks rate setting merely follows these market forces. The crux with this argument now is, that market forces seemingly have established a paradox equilibrium as the reality of negative interest rates collides with the concept of time preference.

For this reason, economists invested in the Austrian business cycle theory challenge the 'oversupply hypotheses of mainstream economists with what one could call the 'policy error' ${ }^{*}$ hypothesis. In a nutshell, this argument holds that interest rate cuts in response to a cyclical economic downswing might conserve obsolete economic structures (zombie enterprises) and as a result hinder the full realization of technological self-actualization and growth potential (Mayer and Schnabl 2019, p. 8). This argument seems especially pertinent if interest rate cuts are a reaction not towards a contraction of the real economy but bear market in equity prices (Hoffmann and Schnabl 2016). However, even if they might help explain why safe real rates and aggregate growth experience simultaneous downward pressure, the 'policy error' hypotheses fails to explain why ultra-low interest rates fail to translate into inflation. Because if negative rates are a policy error and people have a positive time preference, negative rates should result in increases in aggregate demand and inflation. In summary, both mainstream economists 'oversupply hypothesis' as well as Austrian economists 'policy error hypotheses seem fatally flawed ${ }^{+}$.

This is why I now propose yet another perspective from which to explore the certainly puzzling phenomenon of safe real rates of zero. To develop this perspective, I choose a different methodology than the authors summarized above: instead of searching for some form of economic activity as an

\footnotetext{
${ }^{*}$ This, obviously, is a slight euphemism as some forty years of policy errors (by all the world's major central banks, that is) do scream 'insinuation of malevolence' or, in even franker terms, conspiracy theory.

'This might be why the Bank of England's Paul Schmelzing has recently developed a fascinating analyses of historical interest rates which comes to the beautifully simple conclusion that "global real rates have shown a persistent downward trend over the past five centuries" (Schmelzing 2020, p. 2). From this standpoint, the great moderation in rates from 1980 onwards appears to be simply the latest embodiment of a suprasecular trend.
} 
independent variable to explain rate development, I argue that - at least in our age of fiat currency economic theory itself is driving rates. Specifically, I argue that by equating the riskless return with the short-term interest rate, Black and Scholes state a tautology and imply that both rates shall be zero. Let me try to develop this argument in some further detail.

\section{The role of option pricing theory to explain the conundrum}

At one point in their seminal paper "The Pricing of Options and Corporate Liabilities", Fischer Black and Myron Scholes state that "the return on the equity in the hedged position is certain (...) [and thus] the expected return on the hedged position must be at the short term interest rate" (Black and Scholes 1973 , p. 642). However, if risk and return are causally linked, would a riskless return at the bottom of the risk/return matrix not shift the expected returns of all risk assets upward as every rational investor would now demand a return in excess of the risk that he/she is carrying? Moreover, would such a shift not result in an expansion of capitals share of national income? Possibly, but only if the riskless return exceeds the rate of inflation, namely if the safe real rate exceeds zero because a real return of zero seems to be the equilibrium price for a riskless investment. However, in the years immediately following Black and Scholes' construction, real interest rates were negative, i.e. inflation exceeded short-term interest rates (Yi and Zhang 2016).

I now argue that this context concealed the profound implications of the theoretical derivation of the hedged position at its beginning. Only when real interest rates became positive again in the late-1970s and early-1980s the implication of the hedged position became operational. Now equity returns started to outdo economic growth, resulting in a rise of capital's share of national income. Stated in Piketty's terms, rather than this being a 'natural' state of affairs, it is the implications of Black and Scholes' equating of riskless and short-term rates that makes $r>g$. One clear advantage of this way of looking at the economic history of the past 40 years of so is that allows to explain why - after some 70 years of downward pressure - capitals share in national income started to rise again (Piketty 2014).

Excess capital. The missing link between the 'great moderation' and the 'great polarization'

Mainstream economic theory claims that it was the Volcker Fed's management of inflation expectations which tamed inflation and resulted in a steady economic expansion at moderate inflation, a phenomenon know as the 'great moderation' (Bernanke 2004). However, it was said 'moderation' which also saw the diminishment and division of the American middle class and sowed the seeds of the current age of what I call here the great polarization (Rose 2016). From the perspective developed here, it appears that the missing link between the phenomena of a steadily growing economy and an equally steadily decreasing rate of inflation was the re-creation of positive real rates around 1980 . This is because, as was argued above, under the assumptions of the Black and Scholes model, positive real rates translate into an upward shift of return expectation for all risk assets, or, in other words, into a re-distribution of wealth from labor to capital. It was this re-balancing of the distribution of the national income which tamed inflation because the excess returns generated by riskless investments provided investors with excess capital. By excess capital I mean capital for which no immediate reinvestment possibility, e.g. an expansion of capacity, exists. The reason for this dearth of new investment possibilities was, of course, that the diminished income expectations of employed labor resulted in a, compared to prior decades, diminished economic expansion (Streek 2013). The result was a situation in which excess capital was invested in secondary markets, inflating all assets (including government bonds and thus decreasing their yields) but not wages. The great moderation is thus based on a new class divide between riskless returns for the owners of excess capital and stagnating wages for everyone else. A link to the great polarization seems plausible (see also Abramowitz, 2015). 


\section{Conclusion}

Put differently, parts of the spectacular capital gains as well as the collapse on real rates since around 1980 were not the result of entrepreneurial risk and ingenuity but rather extracted from labor's share of national income. As this shift in fortunes arguably weakens the demand side and slows trend line growth, it results in a situation in which capital income exceeds real investment opportunities. Excess capital is now funneled into secondary markets, resulting in asset price inflation. This interrelation obviously also reveals itself in the economic history of the past 40 years, which has seen spectacular rises in the real prices of almost all asset classes.

Nonetheless, theoretically and over the long run, there is no such thing as a free lunch or riskless return and the common denominator of the above trends is that they are not sustainable. Safe real rates cannot fall much lower, as otherwise people will hold cash, gold, bitcoins and the like. Capital's share of national income cannot continue to rise much further as serious social and political dislocations from a prolonged period of both low real economic growth and an increase in capitals share of national income have already started to show. Certainly, it cannot exceed one hundred percent. Finally, it seems unlikely that asset prices can continue to rise indefinitely, as ultimately Black and Scholes' conception of the hedged position implies a political economy in which not only interest and inflation but also growth is trending towards zero.

\section{References:}

Abramowitz, Alan (2015). The New American Electorate: Partisan, Sorted, and Polarized. In Thurber \& Yoshinaka (Eds.), American Gridlock: The Sources, Character, and Impact of Political Polarization (pp. 19-44). Cambridge: Cambridge University Press.

Bernanke (2004), "The Great Moderation”, federalreserve.gov, (accessed May 9, 2020)

Black, Fischer, and Scholes, Myron (1973), "The Pricing of Options and Corporate Liabilities," Journal of Political Economy 81, no. 3 (May-June 1973): 637-654.

Hoffmann, Andreas, and Schnabl, Gunther (2016), "Adverse Effects of Unconventional Monetary Policy", Cato Journal, $449-484$.

Lunsford, Kurt G., and West, Kenneth D. (2019), "Some Evidence on Secular Drivers of US Safe Real Rates," American Economic Journal: Macroeconomics 11, no. 4 (October 2019): 113-139.

Piketty, Thomas (2013), “Das Kapital im 21. Jahrhundert", München : C. H. Beck.

Mayer, Thomas and Schnabl, Gunther (2019), "Reasons for the Demise of Interest: Savings Glut and Secular Stagnation or Central Bank Policy?" Available at SSRN: https://ssrn.com/abstract $=3478451$ or http://dx.doi.org/10.2139/ssrn.3478451 (accessed May 9, 2020)

Rose, Stephen 2016, "The Growing Size and Incomes of the Upper Middle Class", Report, The Urban Institute: 1-23.

Streeck, Wolfgang 2013, Gekaufte Zeit. Berlin: Suhrkamp.

Yellen, Janet L. 2016. "The Federal Reserve's Monetary Policy Toolkit: Past, Present, and Future." Paper presented at the Designing Resilient Monetary Policy Frameworks for the Future Symposium, Jackson Hole, WY.

Yi, Kei-Mu, and Zhang, Jing. 2016. "Real Interest Rates over the long Run. Decline and convergence." Federal Reserve Bank of Minneapolis Economic Policy Papers. 